\title{
Origin and emplacement of syn-orogenic Variscan granitoids in Iberia the Beiras massif
}

\author{
M. Rosário Azevedo \\ Departamento de Geociências, Universidade de Aveiro, Aveiro, Portugal \\ Email:mrosario@geo.ua.pt
}

Beatriz Valle Aguado

Departamento de Geociências, Universidade de Aveiro, Aveiro, Portugal Email: baguado@geo.ua.pt

\section{John Nolan}

Earth Science T. H. Huxley School, Imperial College, London, United Kingdom Email:j.nolan@ic.ac.uk

\author{
M. Estela Martins \\ Departamento de Geociências, Universidade de Aveiro, Aveiro, Portugal \\ Email:mmartins@geo.ua.pt \\ Jorge Medina \\ Jorge MEDINA 1 \\ Departamento de Geociências, Universidade de Aveiro, Aveiro, Portugal \\ Email:jmedina@geo.ua.pt
}

Keywords: Iberian Massif, Portugal, Variscan post-collisional magmatism, U-Pb geochronology, peraluminous granites, calc-alkaline granites

\begin{abstract}
The Beiras batholith consists of four main Variscan granitoid suites intruded into metasediments of Proterozoic-Cambrian and Palaeozoic age in Central Northern Portugal: a) the early, syn- $\mathrm{D}_{3}$ granodiorite-monzogranite suite $(314-311 \mathrm{Ma})$; b) the highly peraluminous syn- $\mathrm{D}_{3}$ two-mica / leucogranite suite $(308 \mathrm{Ma})$; c) the late-post- $\mathrm{D}_{3}$ granodioritemonzogranite suite $(306 \mathrm{Ma})$ and (d) the late-post- $\mathrm{D}_{3}$, peraluminous, biotite-muscovite granite suite (300-295 Ma). Major, trace and isotopic data suggest that the S-type synkinematic two-mica granites result from moderate degrees of partial melting under vapour absent conditions of middle crustal metasedimentary sources comparable to the Proterozoic-Cambrian metapelite-metagraywacke units presently exposed in the studied area. A major contribution from metaigneous lower crust materials and/or interaction with mantle derived magmas appears to be required to produce the early, syn- $\mathrm{D}_{3}$ granodiorite-monzogranite suite. The emplacement of large volumes of late-post-kinematic granites showing decoupled high$\mathrm{K}$ calc-alkaline and peraluminous signatures documents the importance of combined fractional crystallization and mixing processes (AFC) in granite petrogenesis. In a scenario of post-collisional re-equilibration of a thickened lithosphere, asthenospheric mantle upwelling
\end{abstract}


and underplating of abundant basaltic melts at base of the crust is thought to have lead to widespread dehydration melting of lower- to mid-crustal lithologies and consequent formation of peraluminous granite magmas (syn- $\mathrm{D}_{3}$ two-mica granites). Mixing to various degrees of anatectic crustal melts with a juvenile asthenospheric mantle component is considered the major controlling process involved in the production of the late-post- $\mathrm{D}_{3}$, high-K calc-alkaline suite. Concomitant fractional crystallization can explain the geochemical signatures of the more evolved rocks, including those of the late-post- $\mathrm{D}_{3}$, peraluminous, biotite-muscovite granites. 


\section{Table of Contents}

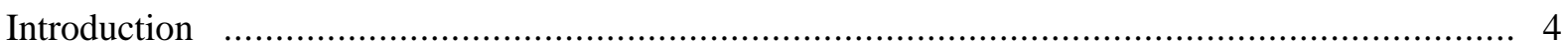

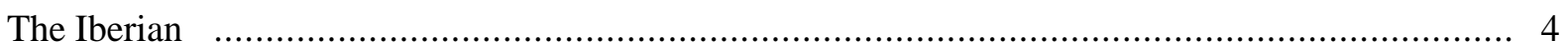

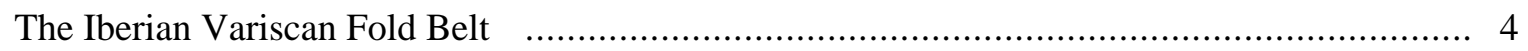

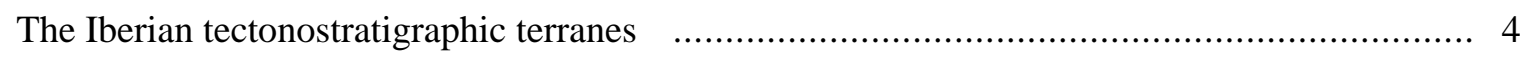

Granitoid plutonism in the Iberian autochthon terrane

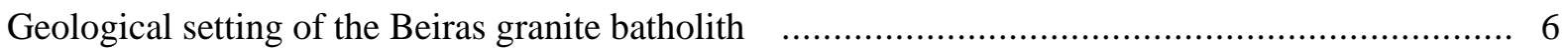

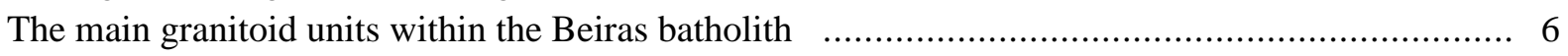

Early, syn- $\mathrm{D}_{3}$ granodiorite-monzogranite suite - Maceira and Casal Vasco granites $\quad \ldots \ldots \ldots \ldots \ldots . . . . . .7$

Syn- $\mathrm{D}_{3}$ peraluminous two-mica / leucogranite suite - Junqueira granite $\quad$............................. 7

Late to post- $\mathrm{D}_{3}$ granodiorite-monzogranite suite - Cota-Viseu granite $\quad$............................... 7

Late to post- $\mathrm{D}_{3}$ biotite-muscovite granite suite - Freixiosa-Alcafache, Dão and Calde granites

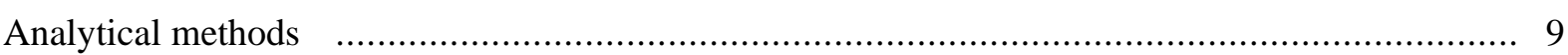

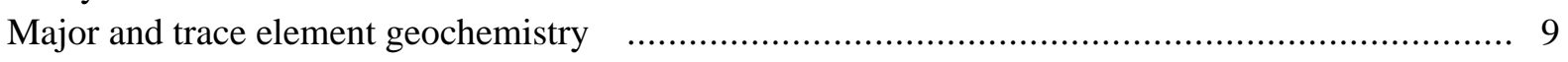

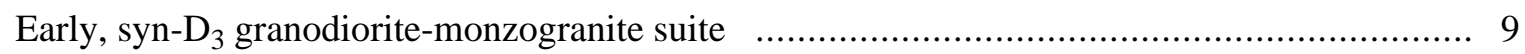

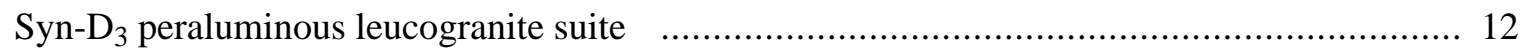

Late- post- $\mathrm{D}_{3}$ granodiorite-monzogranite and biotite-muscovite granite suites $\quad$...................... 13

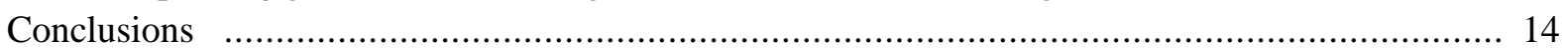

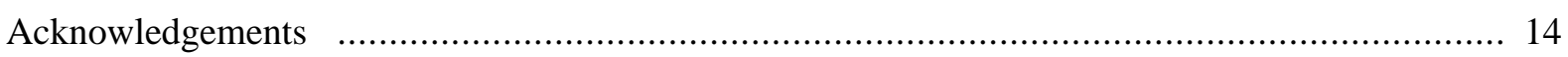

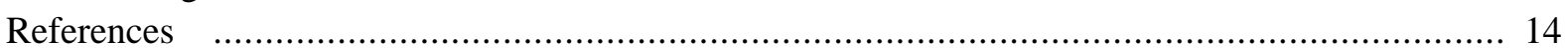

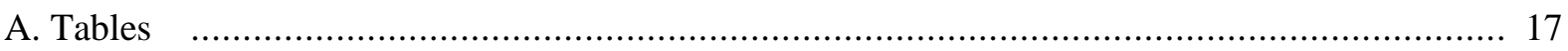




\section{Introduction}

In the study of the evolution of orogenic belts, granites are indispensable sources of information. Age relations, elemental and isotopic compositions, fabrics and three-dimensional forms provide further insights as to the growth and recycling of the continental crust and give pivotal clues to the identity of unexposed basement terranes.

The emplacement of granite batholiths is often considered to occur during long and continuous magmatic processes. This view has important consequences on major issues such as thermal evolution of orogenic belts and tectonic control of granitoid emplacement. It has been demonstrated that a large apparent age range is generally an artefact, caused by the use of inadequately precise dating methods (e.g. Schaltegger, 1997). The Rb-Sr whole-rock isochron method is plagued by variable initial $87 \mathrm{Sr} / 86 \mathrm{Sr}$ ratios, limited spread of $\mathrm{Rb} / \mathrm{Sr}$ ratios and relatively easy post-magmatic disturbance of the isotopic system. In contrast, the $\mathrm{U}-\mathrm{Pb}$ ages obtained by Isotope Dilution and Thermo-Ionisation Mass Spectrometry (ID-TIMS) have the potential to unravel the precise timing of granitoid magma generation and emplacement.

In this paper, we present a synthesis of available structural, petrologic, geochemical and (ID-TIMS) U-Pb geochronological data for the Beiras granite batholith. The significance of this work is discussed in the general context of the Iberian Variscan Belt, and in terms of the thermal conditions required to generate large volume of granite magmas in collisional orogens.

\section{The Iberian}

\section{The Iberian Variscan Fold Belt}

The Variscan orogeny marks the amalgamation of continental plates to form the supercontinent Pangaea in the Upper Palaeozoic. From a comparison between the existing plate tectonic models, it is clear that the number of Variscan oceans and their relative importance to the evolution of the Variscan orogen is still a matter of much debate. Despite these differences, the majority of the authors accept the view that the late Palaeozoic Variscan orogeny involved the closure of the Rheic Ocean, bordering Gondwanan France and Iberia.

The Iberian Massif represents a well-exposed cross section of continental crust affected by Variscan continentcontinent collision during Late Devonian to Carboniferous. It is mainly composed of folded, thrusted and metamor- phosed rocks of late Precambrian and Palaeozoic age and large batholiths of granitoids emplaced during and after collisional tectonics. According to Ribeiro et al. (1990) and Quesada (1991), the evolution of the Iberian Variscan Fold Belt can be described in terms of accretion of a number of tectonostratigraphic terranes with contrasting geological histories, through a long and complex process involving subduction and eventual obduction, followed by oblique convergence and transcurrent faulting.

\section{The Iberian tectonostratigraphic terranes}

Ribeiro et al. (1990), Quesada (1990, 1991) and Shelley and Bossière (2000) distinguished the following accreted terranes within the Iberian Massif:

1. (1) The Iberian autochthon terrane, comprising the Cantabrian Zone (CZ), the West Asturian Leonese Zone (WALZ) and the Central Iberian Zone (CIZ) and consisting of a Proterozoic basement with Gondwanan affinities, covered by lower-middle Palaeozoic shelf sediments (Fig. 1). In the northern part of the CIZ, the Palaeozoic succession is underlain by the Ollo de Sapo acid plutonics emplaced in the Early Ordovician (Gebauer et al., 1993).

Figure 1. Major geotectonic zones of the lberian Massif
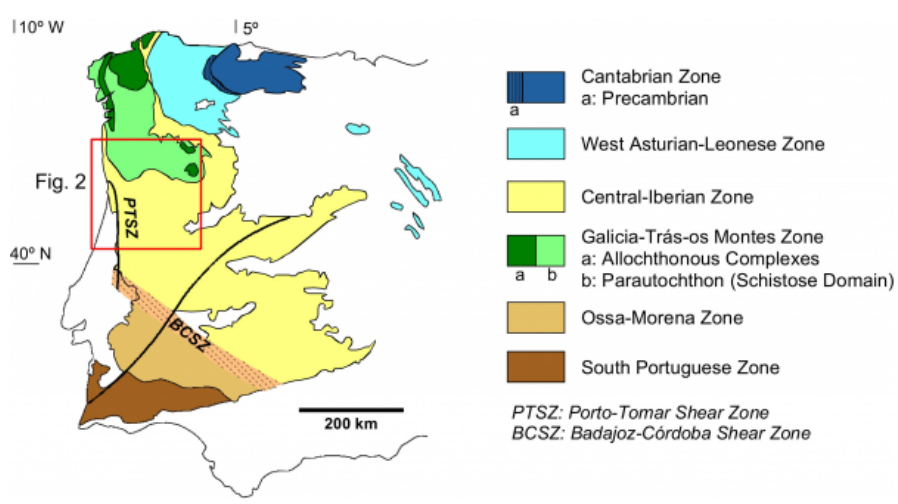

Major geotectonic zones of the lberian Massif (modified from Julivert et al., 1974 and Farias et al., 1987). The location of Fig. 2 is indicated.

2. The Northwest overthrust terranes, represented by the allochthonous nappes of the Galicia Tràs-os-Montes Zone (GTMZ) (Fig. 1). These include klippe with ophiolitic catazonal complexes (Cabo Ortegal, Ordenes, Bragança and Morais), overthrusted by sheets of Precambrian basement rocks and Palaeozoic clastic cover sediments. 
3. The Ossa Morena terrane (OMZ), containing oceanic and volcanic arc material of Cadomian age, covered by Palaeozoic rocks with a more distal character than those of the CIZ (Fig. 1).

4. The Pulo de Lobo oceanic terrane composed of Ordovician-Silurian oceanic lithosphere and low to middle Devonian turbidites which are thought to represent an accretionary prism. Both the Pulo do Lobo and the OssaMorena terranes are overstepped by Late Devonian and/ or Lower Carboniferous flysch sediments.

5. The exotic South Portuguese terrane (SPZ) formed by pre- to syn-orogenic, shelf type deposits of Upper Devonian and Carboniferous age, on top of an unexposed basement of unknown origin (Fig. 1). The SPZ is separated from the Iberian terrane by the Pulo de Lobo oceanic unit (Silva et al., 1990). This suture zone is believed to represent the remnants of the Rheic Ocean (Capdevila and Mougenot, 1988)

As a result of the presence of large, northward and southward overthrusts, the Variscan fold belt has a broad fan-like aspect (Matte, 1986). This bilateral symmetry is accompanied by an outward migration of deformation, metamorphism and granite emplacement through time. A consistent decrease in the age of tectono-metamorphic events from the internal to the external zones of the orogen has been reported by several authors (e.g. Matte and Burg, 1981; Ribeiro, 1981; Matte, 1986).

In the internal zones, collisional tectonics was contemporaneous with and immediately followed by rapid exhumation of crystalline complexes, voluminous granite intrusions and high temperature / low pressure metamorphism (e.g. Burg et al., 1994; Schulmann et al., 2002).

\section{Granitoid plutonism in the Iberian autochthon terrane}

With a few possible exceptions, the Variscan plutonism in the Iberian autochthon is largely unrelated to the subduction of the oceanic crust dated at 380-390 Ma (Dallmeyer and Gil Ibarguchi, 1990; Peucat et al., 1990). The absence of linear belts resembling those of the South American Cordillera Belt (Atherton, 1984; 1993) and the scarcity of typical I-type granites certainly supports the above assumption.

The majority of the Variscan granitoids from the Iberian autochthon terrane were emplaced 340 to 270 million years ago (Ortega and Gil Ibarguchi, 1989). Regional structural constraints show that granite emplacement post-dates syncollisional deformation $\left(\mathrm{D}_{1}+\mathrm{D}_{2}\right)$ and is predominantly correlated with the last Variscan deformation phase $\left(D_{3}\right)$, which is marked by vertical folding and important intracontinental shearing (Noronha et al., 1981; Iglesias and Ribeiro, 1981; Díez Balda et al., 1990).

According to their relationships with the $\mathrm{D}_{3}$ deformation phase, the Iberian Variscan granitoids have been subdivided into two major groups: (a) syn-kinematic (340-320 $\mathrm{Ma}$ ) and (b) late-post-kinematic granites (315-270 Ma) (Oen, 1970; Capdevila et al., 1973; Ferreira et al., 1987; Pinto et al., 1987) (Fig. 2). The range of emplacement ages for these granitoids is mainly based on $\mathrm{Rb}$-Sr whole-rock radiometric data and points to a broadly continuous evolution in time. However, recent high precision $\mathrm{U}-\mathrm{Pb}$ dating reveal that the syn- to post-kinematic Variscan granitoids may have been intruded during several, discrete, shortlived events, over a c.a. 20 Ma timespan (Valle Aguado et al., 2005).

\section{Figure 2. Distribution of Variscan granitoids}

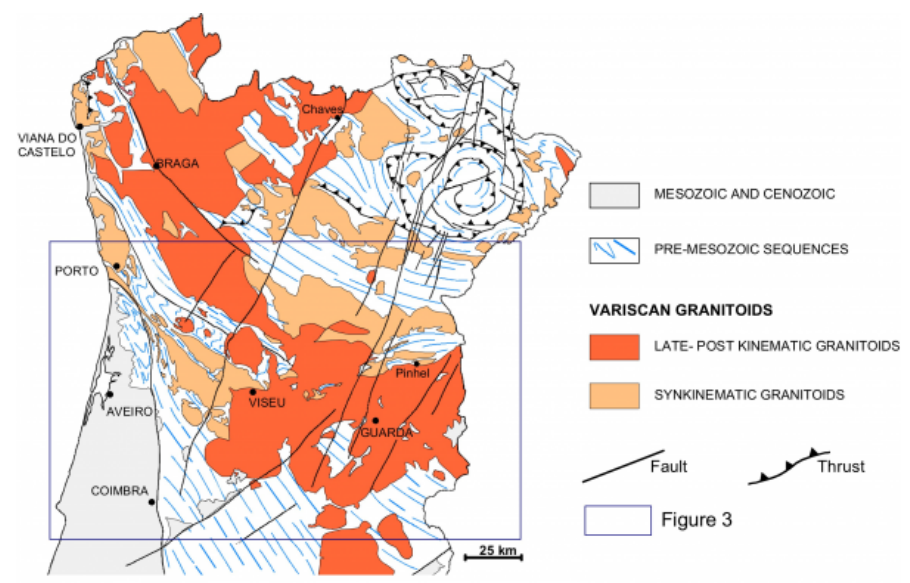

Distribution of Variscan granitoids in the Central Iberian Zone (modified from Ribeiro et al., 1972).

From the petrological and geochemical point of view, the Iberian granitoids have been classified into two main suites: (a) strongly peraluminous leucogranites and twomica granitoids, and (b) calc-alkaline granodiorites and biotite monzogranites, associated with minor intrusions of basic and intermediate rocks. These two granitoid series cannot be exclusively assigned to any particular group of ages. Synkinematic and late-post kinematic plutons of both granite types are found all over the Iberian Massif (Ferreira 
et al., 1987; Pinto et al., 1987; Ortega and Gil Ibarguchi, 1989).

Most petrogenetic models favour an origin by partial melting of pure metasedimentary crustal sources for the highly peraluminous two-mica granites and leucogranites (true S-type granites) (e.g. Reavy, 1989; Beetsma, 1995). However, Holtz and Johannes (1991) claim that the upper crustal metaigneous lithologies (orthogneisses) can also yield peraluminous melts and should therefore be regarded as potential source rocks for the group of peraluminous granitoids.

On the other hand, the I- and I-S transitional granitetypes (granodiorite-monzogranite suites) have been alternatively interpreted as products of: (a) hybridization of felsic crustal melts with mantle-derived magmas, followed by further contamination and fractional crystallization (e.g. Castro et al., 1994; Dias and Leterrier, 1994, Beetsma, 1995; Azevedo and Nolan, 1998; Dias et al., 2002) or (b) partial melting of heterogeneous lower crustal metaigneous sources (e.g. Villaseca et al., 1998).

\section{Geological setting of the Beiras granite batholith}

The Beiras granite batholith is located in the CIZ, well within the Iberian Authochthon terrane (Fig. 3). It was emplaced into metasediments of Proterozoic-Cambrian to Upper Carboniferous age, variably affected by the main Variscan deformation phases $\left(D_{1}, D_{2}\right.$ and $\left.D_{3}\right)$.

\section{Figure 3. Simplified geological map}

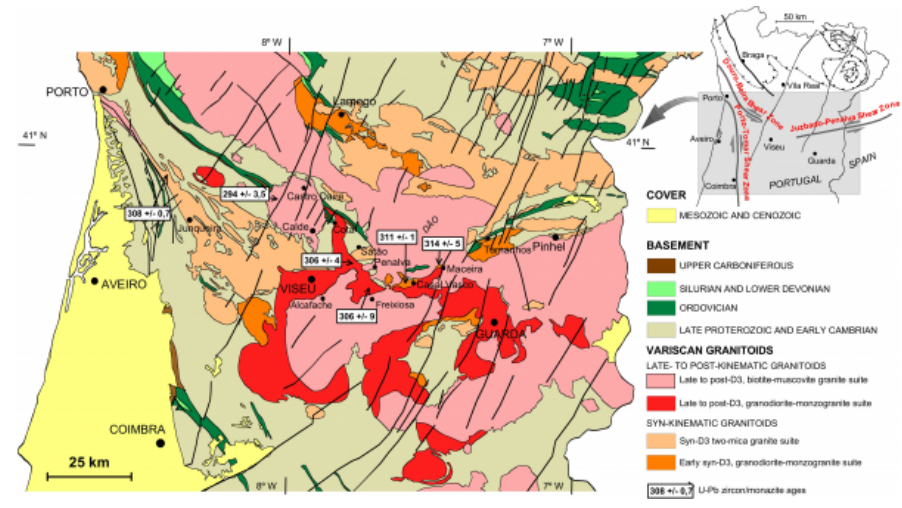

Simplified geological map and tectonic setting of the Beiras region. U-Pb ages of the Beiras batholith from Mota Leite et al. (2005) (Calde granite) and Valle Aguado et al. (2005) (Junqueira, CotaViseu, Casal Vasco and Maceira granitoids).
The pre-Ordovician lithologies constitute a thick and monotonous megasequence of metapelites and metagreywackes, generally referred to as the "Complexo Xisto Grauváquico ante-Ordovícico" (CXG) (Carrington da Costa, 1950; Teixeira, 1954). A late Proterozoic to Cambrian age has been generally assumed for the CXG.

The post-Cambrian Palaeozoic stratigraphic record is exposed in the core of the Porto-Sátão Syncline and includes a succession of Ordovician, Silurian, Lower Devonian and Upper Carboniferous deposits (Fig. 3). These megasequences can be grouped into two main units: a) the pre-orogenic to syn-orogenic materials of Lower Ordovician to Lower Devonian age and b) the post-orogenic unmetamorphosed, continental, coal-bearing deposits of Upper Carboniferous age, formed in a narrow intramontane limnic tectonic basin.

According to Dallmeyer et al. (1997) and Ábalos et al. (2002), Variscan crustal thickening started around $360 \mathrm{Ma}$ in the CIZ autochthon, with the $\mathrm{D}_{1}$ deformation phase inducing prograde metamorphism of Barrovian type. During the Early-Middle Carboniferous, the $\mathrm{D}_{1}$ contractional structures were variably overprinted by a major syn-collisional $\mathrm{D}_{2}$ extensional event attributed to a large-scale gravitational collapse of the thickened continental crust (e.g. Escuder Viruete et al., 1994; Díez Balda et al., 1995; Valverde Vaquero, 1997; Ábalos et al., 2002; Valle Aguado et al., 2005).

Late stage $\mathrm{D}_{3}$ deformation is related to three crustalscale transcurrent shear zones (Fig. 3): the Porto-Tomar dextral shear zone (PTSZ), the Douro-Beira sinistral shear zone (DBSZ) and the sinistral Juzbado-Penalva shear zone (JPSZ) (Ribeiro et al., 1980; Iglesias and Ribeiro, 1981; Dias, 1994; Valle Aguado et al, 2000). It is generally agreed that these three shear zones have accommodated part of the shortening related to the final stages of the continental collision. $\mathrm{D}_{3}$ deformation occurred under greenschist facies retrograde conditions at higher crustal levels whilst, in lower crustal levels, high temperatures could have locally persisted as a result of the high thermal gradients inherited from $\mathrm{D}_{2}$ and the intrusion of synkinematic granitoids (Dallmeyer et al., 1997; Ábalos et al., 2002).

\section{The main granitoid units within the Beiras batholith}

The Beiras batholith comprises several intrusive units of four main granitoid suites: a) the early, syn- $\mathrm{D}_{3}$ granodiorite-monzogranite suite; b) the highly peraluminous 
syn- $\mathrm{D}_{3}$ two-mica / leucogranite suite, c) the late-post- $\mathrm{D}_{3}$ granodiorite-monzogranite suite and (d) the late-post- $\mathrm{D}_{3}$, peraluminous, biotite-muscovite granite suite (Fig. 3). Thorough reviews on the petrography and geochemistry of these granites can be found in Schermerhorn (1956), Oen (1958), Ferreira Pinto (1983), Macedo (1988), Reavy (1989), Neves (1991), Silva (1995), Beetsma (1995), Azevedo (1996), Azevedo and Nolan (1998) and Valle Aguado et al. (2005).

\section{Early, syn- $D_{3}$ granodiorite-monzogranite suite - Maceira and Casal Vasco granites}

The early, syn- $\mathrm{D}_{3}$ granodiorite-monzogranite suite is represented by three small plutons intruded syntectonically along the Juzbado-Penalva sinistral shear zone: the Tamanhos, Maceira and Casal Vasco granites (Fig. 3). These granites show heterogeneous deformation that may result in the development of a gneissic foliation. Based on zircon and monazite U-Pb geochronological data (Valle Aguado et al., 2005), the crystallization ages for the Maceira and Casal Vasco intrusions were estimated at $314 \pm 5 \mathrm{Ma}$ and $311 \pm 1 \mathrm{Ma}$, respectively (Fig. 4).

Figure 4. U-Pb zircon/monazite ages

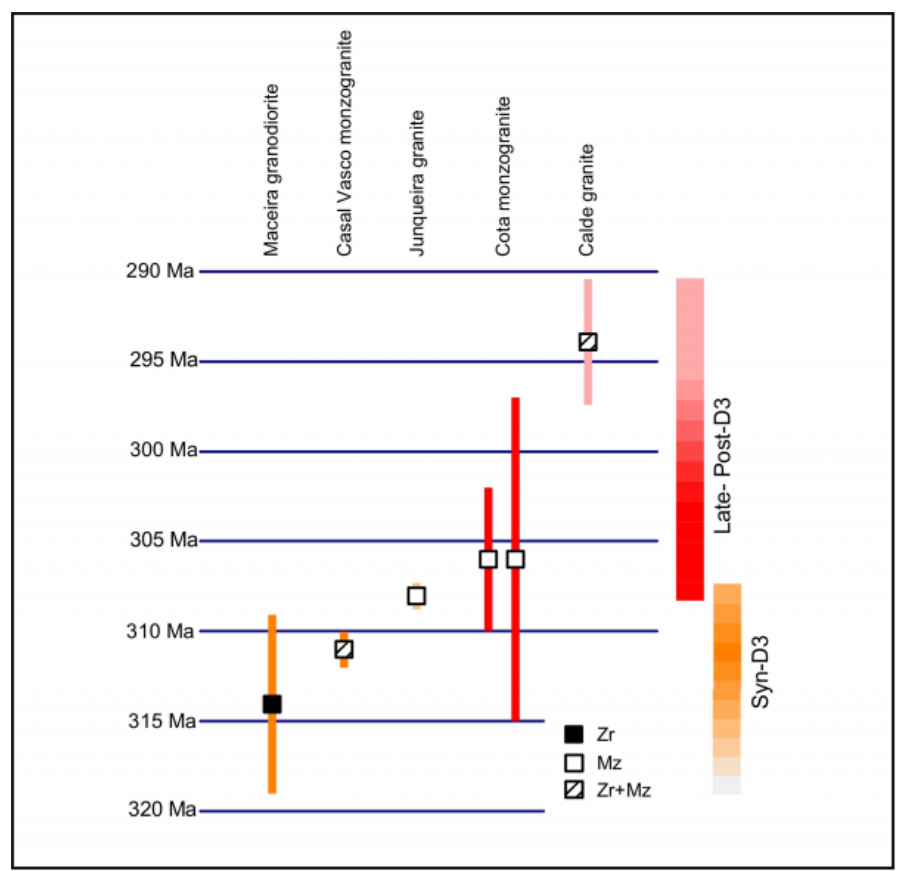

$\mathrm{U}-\mathrm{Pb}$ zircon/monazite ages for the Beiras granite batholith (Mota Leite et al., 2005 and Valle Aguado et al., 2005).

Despite their strong deformation fabric, the Maceira and Casal Vasco biotite gneiss-granites still preserve remnants of igneous granitic textures. The main facies range from medium-grained equigranular to K-feldspar porphyritic. The medium-grained equigranular varieties dominate in the Maceira massif whereas the porphyritic facies are the major lithological type in the Casal Vasco pluton. Mineralogically, the granitoids contain quartz (20-30\%) + plagioclase (An34-An18) (30-35\%) + K-feldspar (? 20\%) + biotite $(>10 \%)+$ apatite + zircon + monazite + opaques \pm muscovite. Fibrolite needles and andalusite grains were occasionaly found in some samples of the Casal Vasco granitoids. Mafic microgranular enclaves (MME) are present in both rock units.

\section{Syn- $D_{3}$ peraluminous two-mica / leucogranite suite - Junqueira granite}

The syn- $\mathrm{D}_{3}$ peraluminous granitoids of the Junqueira Serra da Freita massif crop out as broadly concordant mesozonal plutons in the core of a NW-SE trending, $\mathrm{D}_{3}$ megascopic antiformal structure - the Porto-Viseu Belt (Fig. 3).

Syntectonic intrusion is inferred from the development of an early NW-SE trending magmatic flow fabric evolving locally into a post-solidus foliation. The main granite facies is a medium-grained equigranular two-mica granite, hosting numerous metasedimentary xenoliths (micaceous restites with sillimanite). It is a typical S-type granite and consists of 27 to $35 \%$ quartz, 22 to $35 \%$ plagioclase (An7An4), 15 to $30 \%$ perthitic K-feldspar, 2 to $8 \%$ biotite and 6 to $12 \%$ muscovite. Sillimanite, apatite, zircon, monazite and ilmenite are present as accessory phases. Monazite microfractions from the Junqueira granite yielded slightly reversely concordant points at an average $207 \mathrm{~Pb} / 235 \mathrm{U}$ age of $307.8 \pm 0.7 \mathrm{Ma}$ (Valle Aguado et al., 2005) (Fig. 4).

\section{Late to post- $D_{3}$ granodiorite-monzogranite suite - Cota-Viseu granite}

The Cota-Viseu coarse porphyritic biotite monzogranites occur as a large, discordant, irregularly shaped intrusion, more than $75 \mathrm{~km}$ long and $35 \mathrm{~km}$ wide (Fig. 3), bearing little or no petrographical evidence of solid state deformation. The granite is spatially associated with minor bodies of basic and intermediate rocks (gabbro-norites, monzodiorites, quartz monzodiorites and granodiorites) and contains abundant mafic microgranular enclaves (MME).

Mineralogically, the Cota-Viseu granite consists of Kfeldspar megacrysts up to $8 \mathrm{~cm}$ long set in a medium- to coarse-grained groundmass of quartz, plagioclase 
(An15-32), K-feldspar (mostly perthitic microcline) and biotite (high-Al, low-Mg). Accessory minerals include apatite, zircon, monazite, ilmenite and rare xenotime. The lobate nature of the contacts between the monzogranite and the small stocks of more mafic rocks suggests a synchronous emplacement for the different plutonic units.

The quartz-bearing gabbronorites have mediumgrained, hypidiomorphic granular textures and consist of plagioclase (An50-69), clinopyroxene (augite), orthopyroxene, magnesio hornblende, high-Mg biotite, interstitial quartz and accessory apatite, magnetite, ilmenite and zircon. Sericite, talc, chlorite, calcite and uralitic amphibole form the hydrothermal assemblage. In the quartz-diorites, quartz-monzodiorites and granodiorites, plagioclase ranges from andesine to oligoclase (An15-46), amphibole (magnesio and ferro-hornblende to actinolite) and high-Mg biotite are the dominant mafic phases. The amounts of quartz and perthitic K-feldspar increase towards the more evolved members of the sequence.

Early attempts to date the Cota-Viseu granite using the $\mathrm{Rb}$-Sr whole rock method yielded ages ranging between $282 \pm 6 \mathrm{Ma}$ (Pereira, 1991), $308 \pm 11 \mathrm{Ma}$ (Silva, 1995) and $315 \pm 9$ Ma (Azevedo and Nolan, 1998). Conventional multigrain $\mathrm{U}-\mathrm{Pb}$ analysis of zircon and monazite grains from two samples of the Cota-Viseu coarse porphyritic biotite monzogranite have given ages in the range 305-308 $\mathrm{Ma}$. The $207 \mathrm{~Pb} / 235 \mathrm{U}$ ages obtained in the monazite fractions of both samples are identical within error $(306 \pm 9 \mathrm{Ma}$ and $306 \pm 4 \mathrm{Ma}$, respectively) and appear to reflect the crystallization age of the granite (Valle Aguado et. al. 2005) (Fig. 4). Based on field relationships, a similar age is assumed for the basic and intermediate rocks.

\section{Late to post- $D_{3}$ biotite-muscovite granite suite - Freixiosa-Alcafache, Dão and Calde granites}

The late-post- $\mathrm{D}_{3}$ biotite-muscovite granite suite comprises two large plutonic complexes: the Alcafache-Freixiosa massif (in the centre) and the Dão massif (in the north) (Fig. 3) showing intrusive relationships with the Cota-Viseu coarse porphyritic biotite monzogranite. These granites span a wide spectrum of petrographic types (medium- and coarse-grained inequigranular to fine-, medium- and coarse-porphyritic) and have $25-33 \%$ plagioclase (An1-28), 26-32\% quartz, 25-35\% K-feldspar, 4-6\% high$\mathrm{Al}$, low-Mg biotite and 2-5\% muscovite as major rockforming minerals. K-feldspar (mostly perthitic microcline) is present both as an interstitial groundmass phase and as subhedral megacrysts. However, the K-feldspar megacrysts are generally smaller than those of the coarse porphyritic biotite types. Another important difference between these granites and the Cota-Viseu coarse porphyritic biotite granitoids is the occurrence of muscovite as a significant modal phase. The various facies of the biotitemuscovite granitoids are generally enclave-free although they may contain, in places, sparse biotite schlieren and enclaves of igneous and metasedimentary origin.

$\mathrm{Rb}-\mathrm{Sr}$ whole rock ages for these granites range from 291 $\pm 13 \mathrm{Ma}$ and $293 \pm 10 \mathrm{Ma}$ in the medium grained and finemedium porphyritic varieties of the Freixiosa-Alcafache massif (Azevedo and Nolan, 1998; Silva, 1995) to $287 \pm 7$ $\mathrm{Ma}$, in the medium-coarse porphyritic biotite-muscovite types of the same massif (Silva, 1995).

In the northwest, the Cota-Viseu coarse porphyritic biotite monzogranite is intruded by the Castro Daire composite massif (Fig. 3). This massif, first described by Schemerhorn (1956), consists of five main granitoid units, defining a concentric zonation pattern of progressively less basic compositions from margin to core (Lamelas hornblende-biotite quartz monzodiorite; Castro Daire biotite monzogranite; Calde coarse porphyritic biotite-muscovite monzogranite, Alva and Lamas two-mica monzogranites).

The Calde coarse porphyritic biotite-muscovite granite is the dominant lithological type within the Castro Daire intrusion. It is predominantly composed of quartz, K-feldspar (mostly perthitic microcline) and plagioclase (oligoclase - albite) showing oscillatory and complex zoning. Biotite is the main mafic phase. Muscovite is present in variable amounts. Apatite, zircon, monazite, xenotime and opaques occur as common accessory phases. Andalusite and masses of fibrolite needles of restitic origin and latestage garnet and tourmaline (schorl) are sporadically observed. Dark igneous enclaves and pelitic inclusions are unevenly distributed throughout this facies.

$\mathrm{U}-\mathrm{Pb}$ zircon and monazite ages for the Calde granite were determined at ETH, Zurich, using conventional isotopic dilution techniques on single-grain fractions (Mota Leite et al., 2005). The zircon population consisted of three acicular to long prismatic grains and yielded overlapping $206 \mathrm{~Pb} / 238 \mathrm{U}$ ages of $294.8 \pm 2.9 \mathrm{Ma}$. The three analysed monazite crystals yielded a $207 \mathrm{~Pb} / 235 \mathrm{U}$ age of $294.1 \pm 3.5$ Ma. In view of the good agreement of the monazite and zircon $\mathrm{U}-\mathrm{Pb}$ ages, it is possible to date the emplacement of 
the Calde coarse porphyritic biotite-muscovite granites at $294 \mathrm{Ma}$ (Fig. 4).

\section{Analytical methods}

Over two hundred representative samples of the various granite units have been analysed for major and some trace elements ( $\mathrm{Ba}, \mathrm{Cr}, \mathrm{Ni}, \mathrm{Sr}, \mathrm{V}, \mathrm{Zr}$ ) by inductively coupled plasma atomic emission (ICP-AES) at the University of London Imperial College (IC). Ferrous iron was determined by titration and $\mathrm{Rb}$ was analysed by flame emission spectrometry (FES). Subsets of these samples have been analysed for REE, Y, Sc and Hf at the University of London Royal Holloway and Bedford New College (RHBNC) using cation exchange separation and ICP-AES (Watkins and Nolan, 1990; 1992). Analytical errors are less than 5\% for most elements. Major-, trace- and rare-earth element data for selected samples of the different granite units are presented in Table 1.

$\mathrm{Sr}$ and $\mathrm{Nd}$ isotopic compositions of the Beiras granitoids are given in Valle Aguado et al. (2005). Based on the available geochronological data, the $87 \mathrm{Sr} / 86 \mathrm{Sri}$ and ?Ndi values were calculated for the following ages: $310 \mathrm{Ma}$ (Maceira and Junqueira granites); $305 \mathrm{Ma}$ (Cota-Viseu granites and coeval basic and intermediate rocks) and $295 \mathrm{Ma}$ (Freixiosa - Mesquitela granites).

\section{Major and trace element geochemistry}

\section{Early, syn- $D_{3}$ granodiorite-monzogranite suite}

The Tamanhos, Maceira and Casal Vasco biotite gneissgranites plot essentially within the field of the monzogranites in the R1-R2 diagram (la Roche et al., 1980) (Fig. 5). Their compositions vary from slightly peraluminous granodiorites to highly peraluminous monzogranites $(\mathrm{SiO} 2=$ $60-72 \%$; A/CNK = 1.0 - 1.37) (Fig. 6) and are characterized by low $\mathrm{A} 12 \mathrm{O} 3 / \mathrm{TiO} 2$ and high $\mathrm{CaO} / \mathrm{Na} 2 \mathrm{O}$ ratios (Fig. 7). As shown by Sylvester (1998), the $\mathrm{CaO} / \mathrm{Na} 2 \mathrm{O}$ ratio in peraluminous melts is predominantly controlled by the plagioclase/clay ratio of the source being therefore unlikely that granite melts with high $\mathrm{CaO} / \mathrm{Na} 2 \mathrm{O}$ ratios could be produced by simple partial melting of mature sedimentary protoliths (plagioclase-poor metapelites). A more immature quartzofeldsphatic-rich (greywackes) and/or metaigneous (tonalites-granodiorites) crustal source may therefore be proposed. However, high $\mathrm{CaO} / \mathrm{Na} 2 \mathrm{O}$ ratios can also result from mixing of strongly peraluminous crustal melts with basaltic magmas (Sylvester, 1998).

\section{Figure 5. R1-R2 variation diagrams}
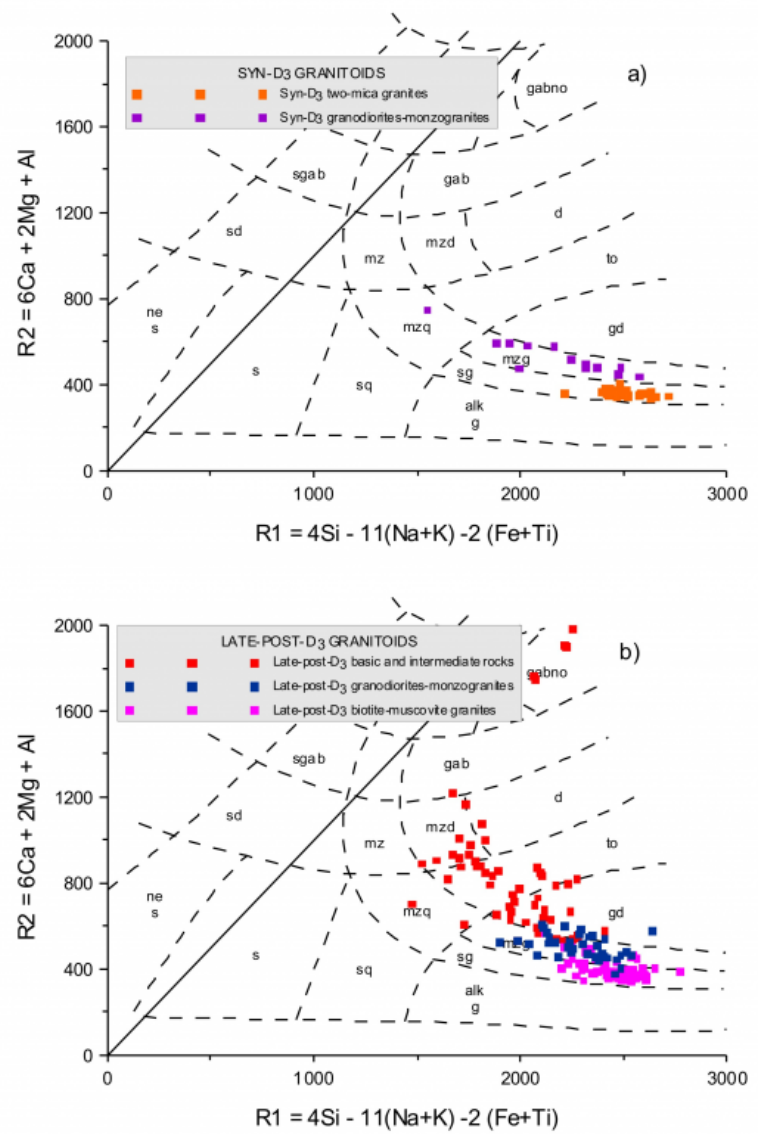

$\mathrm{R} 1-\mathrm{R} 2$ variation diagrams for the Beiras granitoids (a) syn-kinematic biotite-bearing granodioritesmonzogranites and highly peraluminous two-mica granitoids; (b) late-post-kinematic basic and intermediate rocks, biotite monzogranites and biotitemuscovite peraluminous granites. sgab - syenogabbros; sd - syenodiorites; ne $s$ - nepheline syenites; $\mathrm{s}$ - syenites; $\mathrm{mz}$ - monzonites; mzq quartz monzonites; mzd - monzodiorites; gab gabbros; gabno - gabbro norites; $d$ - diorites; to tonalites; gd - granodiorites; mzg - monzogranites; sg - syenogranites; alk $\mathrm{g}$ - alkaline granites. 
Figure 6. A/CNK vs. SiO2 variation diagrams
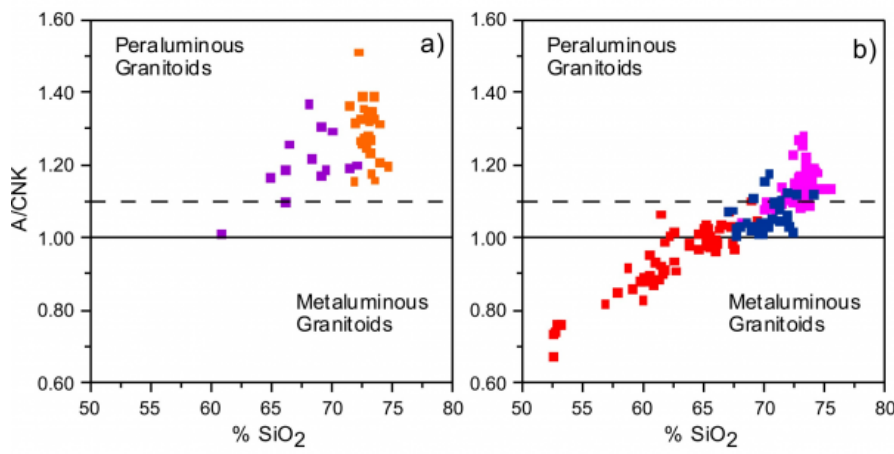

$\mathrm{A} / \mathrm{CNK}$ vs. SiO2 variation diagrams for the Beiras granitoids: (a) syn-kinematic biotite-bearing granodiorites-monzogranites and highly peraluminous two-mica granitoids; (b) late-post-kinematic basic and intermediate intrusive rocks, biotite monzogranites and biotite-muscovite peraluminous granites. Symbols as in figure 5 .

\section{Figure 7. $\mathrm{CaO} / \mathrm{Na} 2 \mathrm{O}$ vs $\mathrm{Al} 2 \mathrm{O} / \mathrm{TiO} 2$}

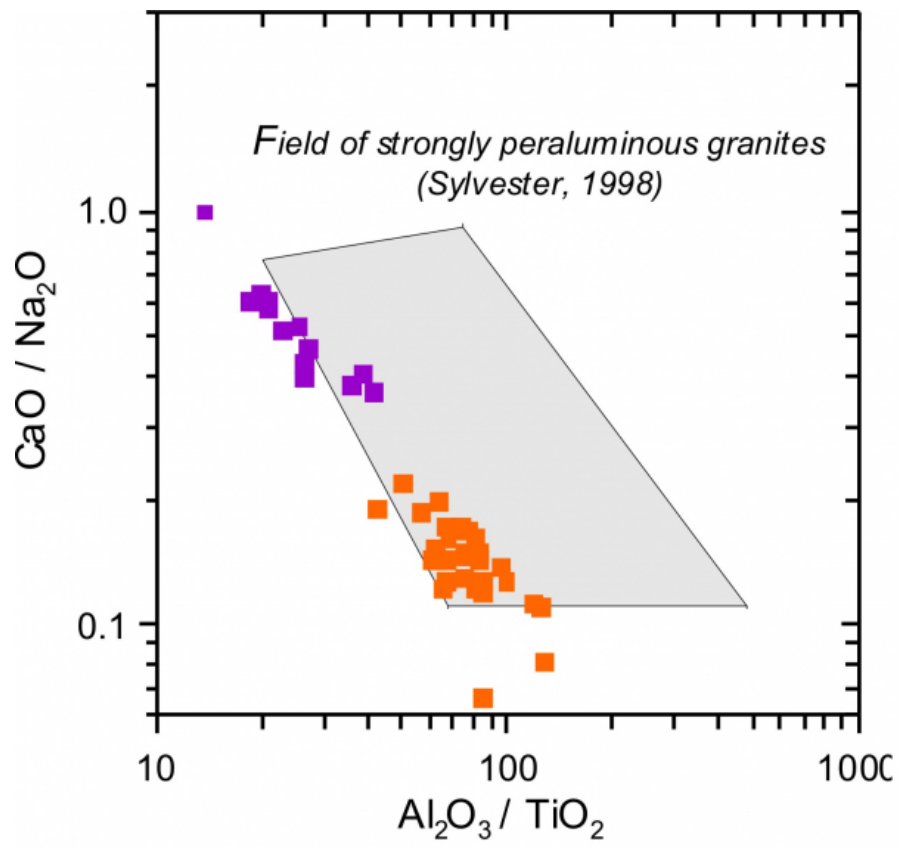

$\mathrm{CaO} / \mathrm{Na} 2 \mathrm{O}$ vs $\mathrm{Al} 2 \mathrm{O} 3 / \mathrm{TiO} 2$ for the Beiras syn-kinematic biotite-bearing granodiorites-monzogranites and highly peraluminous two-mica granitoids Symbols as in figure 5 .

According to the same author, the $\mathrm{Al} 2 \mathrm{O} 3$ contents in the melts derived from anatexis of both pelites and psammites remain nearly constant during the partial melting event due to the stability of aluminous refractory phases, whilst the concentrations of $\mathrm{TiO} 2$ tend to increase with increasing temperature as a result of the progressive breakdown of Tibearing phases (biotite and ilmenite). The low $\mathrm{Al} 2 \mathrm{O} 3 / \mathrm{TiO} 2$ ratios (13-41) and high $\mathrm{CaO} / \mathrm{Na} 2 \mathrm{O}$ ratios (0.3-1.0) displayed by these granitoids suggest generation at high temperatures $\left(875-1000^{\circ} \mathrm{C}\right)$.

Compared to the other granitoid suites of the Beiras batholith, the syn- $\mathrm{D}_{3}$ granodiorite-monzogranites exhibit high to very high $\mathrm{Ba}$ and REE contents $(\mathrm{Ba}=549-2670$ ppm; ?REE = 481-681 ppm), low Rb/Sr ratios $(<0.4)$, significant LREE enrichment $(\mathrm{LaN} / \mathrm{YbN}=34-46)$ and small to moderate Eu negative anomalies $\left(\mathrm{Eu} / \mathrm{Eu}^{*}=0.66-0.24\right)$ (Fig. 8). Trace element normalized patterns for representative samples of the Maceira granodiorites and monzogranites are illustrated in Figure 9. The trace element composition for one sample of the lower crust felsic granulite xenoliths scavenged by early Mesozoic alkaline dykes in the Iberian Massif (Villaseca et al., 1999) was also plotted in the diagram of Figure 9. The Maceira granodiorites and monzogranites are significantly enriched in LILE, LREE, $\mathrm{Zr}$ and $\mathrm{Hf}$ and depleted in HREE, Ti and $\mathrm{Y}$ relative to the felsic granulites. These features are easily reconciled with a petrogenetic model involving low degrees of partial melting of a feldspar-rich orthogneissic source, leaving behind a residue similar to the felsic xenoliths (garnet-, rutile and ilmenite-rich and plagioclase/biotite poor). 
Figure 8. REE chondrite normalized patterns
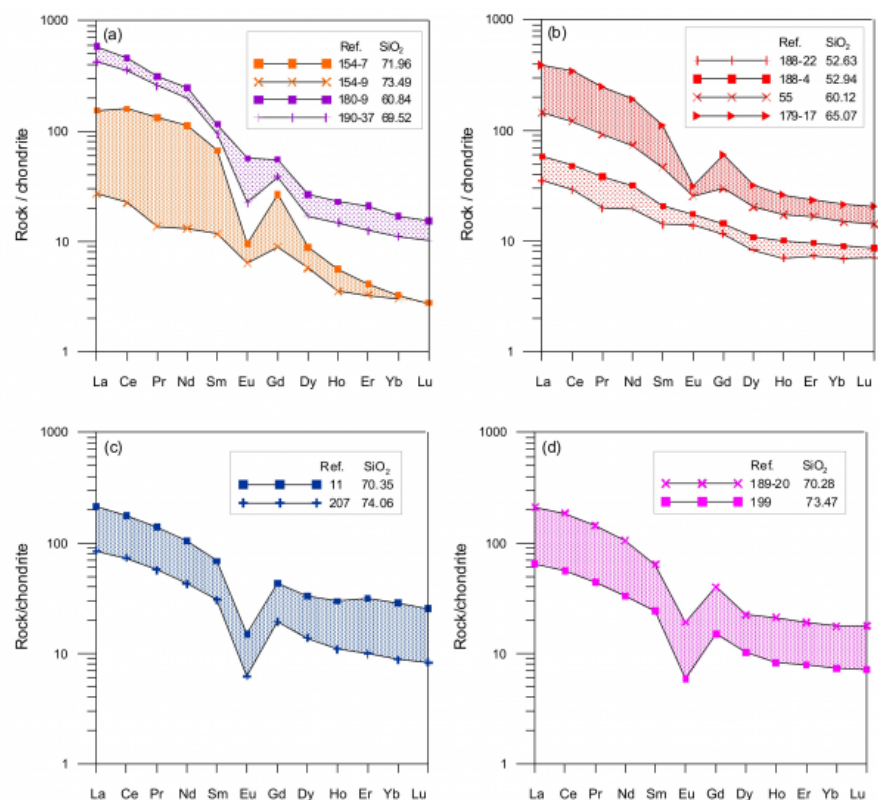

REE chondrite normalized patterns for the Beiras granitoids: (a) syn-kinematic biotite-bearing granodiorites-monzogranites and highly peraluminous two-mica granitoids; (b) late-post kinematic basic and intermediate intrusive rocks; (c) late-post kinematic biotite monzogranites and (d) late-post kinematic biotite-muscovite peraluminous granites. Symbols as in figure 5 . Normalization constants from Evensen et al. (1978). Shadowed areas represent the range of REE chondrite normalized values for each granitoid type.
Figure 9. Primordial-mantle
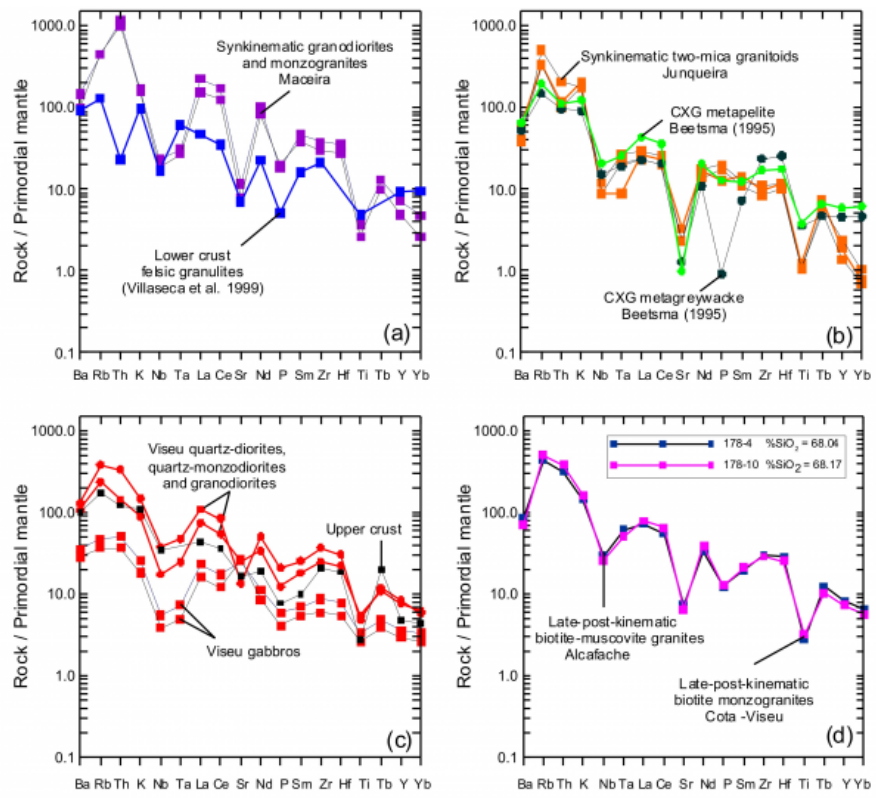

Primordial-mantle normalized trace element patterns for the Beiras granitoids: (a) syn-kinematic biotite-bearing granodiorites-monzogranites; (b) highly peraluminous two-mica granitoids; (c) latepost kinematic basic and intermediate intrusive rocks; (d) late-post kinematic biotite monzogranites and biotite-muscovite peraluminous granites. For comparison, trace element compositions for lower crustal felsic granulites (Villaseca et al., 1999), upper crust Late Proterozoic-Cambrian metasediments (CXG) (Beetsma, 1995) and average upper crust (Taylor and McLennan, 1985) were also plotted. Normalizing constants from Sun and McDonough (1989).

The samples of the Maceira and Casal Vasco granites show relatively unradiogenic $\mathrm{Sr}$ and $\mathrm{Nd}$ isotopic signatures $(87 \mathrm{Sr} / 86 \mathrm{Sri}=0.707-0.710 ;$ ?Ndi $=-3$ to -7$)$ and define a steeply-sloped negative correlation on the ?Sri-?Ndi diagram (Fig. 10). The lack of $\mathrm{Sr}$ and particularly $\mathrm{Nd}$ isotopic homogeneity both within and between the individual units of the suite is not consistent with an origin by partial melting of a single metasedimentary and/or felsic metaigneous crustal protolith and appears to imply mixing of, at least, two distinct source components with contrasting $\mathrm{Sr}-\mathrm{Nd}$ compositions. The isotopic data for several crustal protoliths of the Iberian pre-Variscan basement (age-corrected to $310 \mathrm{Ma}$ ) were also plotted in figure 10. Although there is a close match between the $\mathrm{Sr}-\mathrm{Nd}$ isotopic compositions of the lower crust felsic metaigneous granulites and those 
of the Maceira and Casal Vasco granites, it is also possible to interpret the isotopic signature of this granite suite in terms of crustal contamination of a mantle-derived magma by lower crustal metapelitic granulites.

Figure 10. Nd initial vs. Srinitial variation diagram
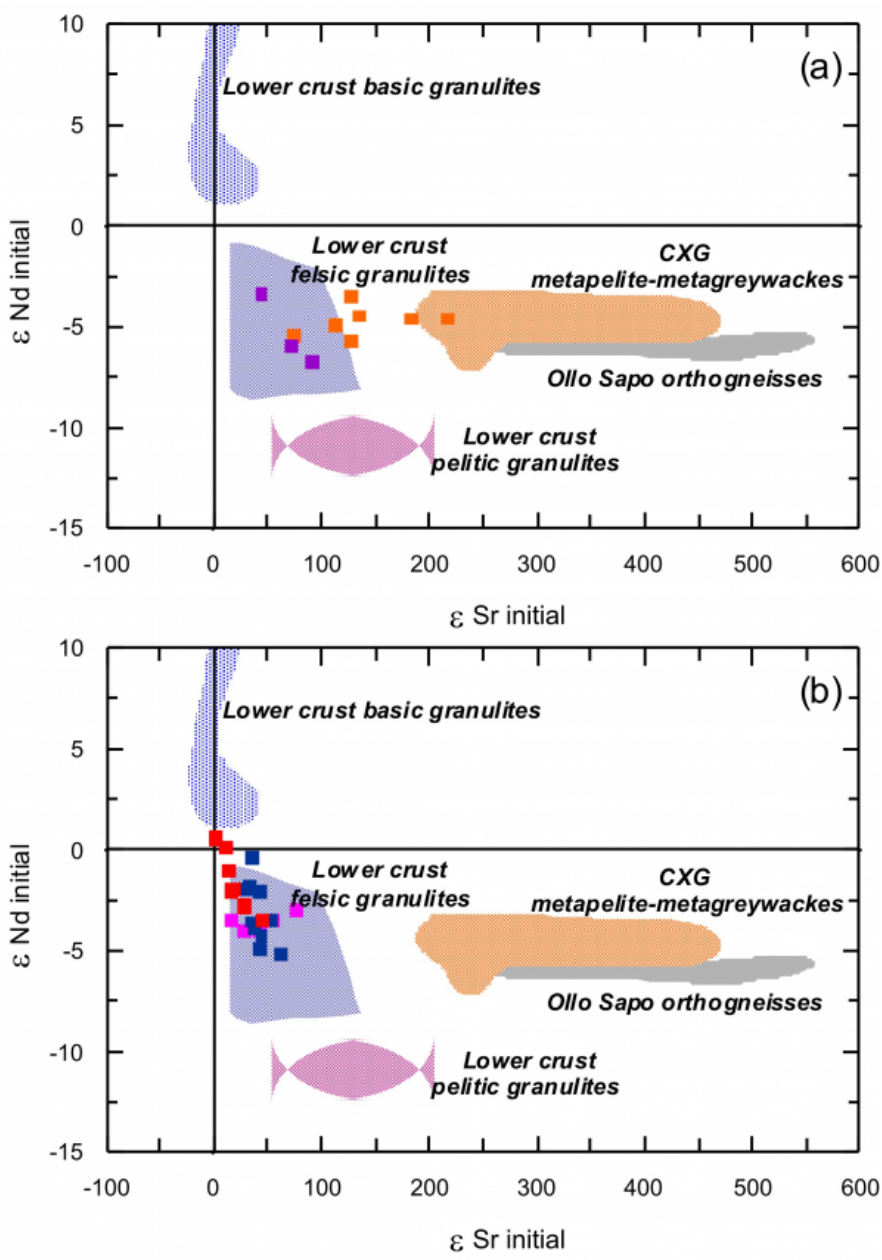

$\mathrm{Nd}$ initial vs. Srinitial variation diagram for the Beiras granitoids: (a) syn-kinematic biotite-bearing granodiorites-monzogranites and highly peraluminous two-mica granitoids; (b) late-post-kinematic basic and intermediate intrusive rocks, biotite monzogranites and biotite-muscovite peraluminous granites. Symbols as in figure 5. The fields of potential crustal protoliths are also shown. Source materials include upper crustal Late ProterozoicCambrian metasediments (CXG) (Beetsma, 1995, Tassinari et al., 1995); orthogneisses from Ollo de Sapo complex (Beetsma, 1995); lower crustal felsic granulites (Villaseca et al., 1999); lower crustal pelitic granulites (Villaseca et al., 1999) and lower crustal basic granulites (Peucat et al., 1990).
As such, two alternative petrogenetic models may be proposed: (a) mixing between mantle-derived gabbroic magmas (low $\mathrm{Rb} / \mathrm{Sr}$ - high $\mathrm{Sm} / \mathrm{Nd}$ end-member) and lower crust pelite materials (high $\mathrm{Rb} / \mathrm{Sr}$ - low Sm/Nd end-member); (b) partial melting of lower crustal felsic metaigneous granulites. Both models can yield similar geochemical signatures and are not clearly distinguished on the basis of $\mathrm{Sr}$ $\mathrm{Nd}$ isotopic data. At the presently level, there is no evidence of basic intrusive rocks associated with the Maceira and Casal Vasco granites. Nevertheless, in a scenario of high temperature collision such as the Variscides, where upwelling asthenosphere was able to rise and invade the crust, the possible contribution of mantle-derived magmas to granite petrogenesis cannot be ruled out.

\section{Syn- $D_{3}$ peraluminous leucogranite suite}

The Junqueira syn- $\mathrm{D}_{3}$ two-mica granitoids show little compositional variation and a strong peraluminous char$\operatorname{acter}(\mathrm{A} / \mathrm{CNK}=1.15$ - 1.50) (Figs. 5 and 6). Silica contents range from 71 to $74 \%, \mathrm{Ca}, \mathrm{Mg}, \mathrm{Ti}, \mathrm{Ba}, \mathrm{Sr}$, ?REE and HFSE contents are low $(\mathrm{CaO}=0.3-0.6 \% ; \mathrm{MgO}=0.2-0.6 \%$; $\mathrm{TiO} 2$ $=0.12-0.36 \% ; \mathrm{Ba}=215-380 \mathrm{ppm} ; \mathrm{Sr}=40-70 \mathrm{ppm} ; ? \mathrm{REE}$ $=35-295 \mathrm{ppm}), \mathrm{Rb} / \mathrm{Sr}$ ratios are high (2-6) and $\mathrm{P} 2 \mathrm{O} 5$ is high but variable. Their REE patterns vary from LREE enriched with large negative Eu negative anomalies (LaN/ $\mathrm{YbN}=47 ; \mathrm{Eu} / \mathrm{Eu}^{*}=0.24$ ) towards less fractionated patterns with slightly negative Eu negative anomalies (LaN/ $\mathrm{YbN}=8 ; \mathrm{Eu} / \mathrm{Eu}^{*}=0.6$ ) (Fig. 8).

The close association between these granites and the migmatites of the high-grade Porto-Viseu metamorphic belt suggests an origin by widespread dehydration partial melting of metasedimentary crustal sources comparable to the CXG metapelite-metagreywacke units presently exposed in the Central Iberian Zone. Estimates of P-T conditions at the time of partial melting range between 8-3 Kbar and 800-600*C (Escuder Viruete et al., 2000). Compared to experimental peraluminous melts produced from plagioclase-poor pelites (Patiño Douce and Johnston, 1991) and plagioclase-rich psammitic gneisses (Patiño Douce and Beard, 1995; Skjerlie and Johnston, 1996), under similar P-T conditions, the Junqueira granites show $\mathrm{CaO} / \mathrm{Na} 2 \mathrm{O}, \mathrm{Al} 2 \mathrm{O} 3 / \mathrm{TiO} 2$ and $\mathrm{Rb} / \mathrm{Sr}$ ratios $(\mathrm{CaO} / \mathrm{Na} 2 \mathrm{O}<$ $0.3 ; \mathrm{Al} 2 \mathrm{O} 3 / \mathrm{TiO} 2=42-130 ; \mathrm{Rb} / \mathrm{Sr}=2-6$ ) more compatible with a derivation from feldspar-poor sources at relatively high temperatures (Sylvester, 1998) (Fig. 6).

In trace element variation diagrams, normalized to primordial mantle (Fig. 9), the compositions of the Junqueira 
granites do not differ significantly from those of the lowgrade metapelites and metagreywackes of the CXG. This suggests that the strongly peraluminous two-mica granites could have been produced by moderate degrees of partial melting of CXG metasediments at middle crustal levels. The relative depletions in $\mathrm{Nb}, \mathrm{Ta}, \mathrm{Ti}, \mathrm{Y}$ and HREE point to the presence of $\mathrm{Fe}-\mathrm{Ti}$ oxides \pm rutile + garnet + biotite in the residual mineral assemblage.

There is a good agreement between the initial ?Nd values of the syn- $\mathrm{D}_{3}$ two-mica granitoids $(-5.7$ to -3.5$)$ and the inferred $\mathrm{Nd}$ isotope compositions for both the CXG metasediments (?Ndi $=-3.7$ to -6.4 ) and the Ollo de Sapo orthogneisses $(? \mathrm{Ndi}=-4.6$ to -6.3$)$ at the time of granite generation. However, the Sr isotopic signature of the Junqueira granites is highly variable and clearly less radiogenic than those of their presumed crustal sources. The observed spread of $\mathrm{Sr}$ initial ratios is coupled with a very narrow range of ?Ndi values and can be ascribed to a wide number of causes: partial re-equilibration of the $\mathrm{Rb}$-Sr system during deformation (Page and Bell, 1986), post-magmatic alteration (Kwan et al., 1992) and disequilibrium partial melting (Allègre and Minster, 1978). Assuming that the $\mathrm{Sr}$ isotopic ratios of both granites and protoliths could have been disturbed by any of these processes, the geochemical and isotopic characteristics of the Junqueira granites are well accounted for by moderate degrees of partial melting of the CXG metasediments under vapour absent conditions as previously proposed by Beetsma (1995).

\section{Late- post- $D_{3}$ granodiorite-monzogranite and biotite-muscovite granite suites}

The different intrusive units of the late-post- $\mathrm{D}_{3}$ CotaViseu batholith define a curvilinear array in the R1-R2 diagram (la Roche et al., 1980) with compositions ranging from gabbro-norites, diorites, monzodiorites, quartz monzodiorites and granodiorites to monzogranites (Fig. 5). The samples of Alcafache-Freixiosa-Dão biotite-muscovite granites plot mainly in the field of the syenogranites, at the extreme acid end of the same trend (Fig. 5). Taken together, these granitoids show a wide compositional range $(\mathrm{SiO} 2=$ $52-75 \% ; \mathrm{MgO}=7.9-0.2 \%$ ) and decoupled high-K calc-alkaline and peraluminous affinities. The least evolved members of the suite are dominantly metaluminous (A/CNK < 1.0), the Cota-Viseu coarse porphyritic biotite monzogranite is slightly peraluminous $(\mathrm{A} / \mathrm{CNK}=0.9-1.12)$ and the more evolved Alcafache-Freixiosa biotite-muscovite gran- ites exhibit peraluminous signatures $(\mathrm{A} / \mathrm{CNK}=1.0-1.22)$ (Fig. 6).

In Harker diagrams, the full spectrum of rock types display almost continuous geochemical trends, indicating a strong genetic link between all units. For increasing $\mathrm{SiO} 2$ contents, $\mathrm{K}, \mathrm{Rb}$ and $\mathrm{Eu} / \mathrm{Eu}^{*}$ increase, $\mathrm{Ca}, \mathrm{Al}, \mathrm{Mg}, \mathrm{Sr}$ decrease and $\mathrm{Fe}, \mathrm{Ti}, \mathrm{Ba}$, LREE, HFSE change from an incompatible to a compatible behaviour. There is a clear hiatus in $\mathrm{SiO} 2$ content $(\mathrm{SiO} 2=53-56 \%)$ between the more primitive compositions (gabbro-norites and diorites) and the dominant biotite granodiorites and monzogranites. However, the occurrence of ubiquitous mixing-mingling relationships between these rock types suggests that opensystem AFC processes may have played a major role in the petrogenesis of the suite. Despite their distinctive peraluminous character, the Alcafache-Freixiosa-Dão two-mica granites show significant compositional overlap with the more evolved members of the Cota-Viseu granodioritemonzogranite sequence and could therefore have been produced from similar sources and processes.

Chondrite-normalised REE patterns for selected samples of these granitoids are presented in Figure 8. The gabbro-norites are characterized by low ?REE contents (48-78), very low LaN/YbN ratios (5-6) and absent or slightly positive Eu anomalies. In contrast, the rocks of intermediate composition exhibit distinctive Eu negative anomalies, highly variable ?REE contents (96-475) and more fractionated REE patterns $(\mathrm{LaN} / \mathrm{YbN}=9-18)$. The Cota-Viseu biotite monzogranites and the two-mica Alcafache-Freixiosa-Dão granites have subparallel REE profiles and show a steady decrease of LREE and increasing negative Eu anomaly with magmatic differentiation. The overall chemical variation of the suite appears to have been largely controlled by crystal-melt fractionation processes and can be accounted for by an AFC model involving contamination of gabbroic magmas by anatectic crustal melts plus fractionation of the following mineral assemblages: (a) plagioclase + orthopyroxene + clinopyroxene, (b) plagioclase \pm clinopyroxene + amphibole + biotite, (c) plagioclase + biotite + K-feldspar \pm apatite + monazite + zircon.

In trace element primordial mantle-normalised diagrams (Fig. 9), all rock units including the gabbro-norites show Nb-Ta-Ti troughs and Th-enrichment, probably reflecting inherited crustal signatures. The LILE, REE and to, a lesser extent, the HFSE increase from the basic to the intermediate rocks $(\mathrm{SiO} 2=52-65 \%)$ whilst $\mathrm{Sr}$ decreases 
(Fig. 9c). For $\mathrm{SiO} 2$ contents greater than 65\%, the LREE decrease and the negative anomalies of $\mathrm{Sr}, \mathrm{P}$ and $\mathrm{Ti}$ tend to become increasingly more pronounced. It is also clear that the Alcafache-Freixiosa-Dão two-mica granites and the Cota-Viseu biotite granites overlap in composition for the same range of $\mathrm{SiO} 2$ contents (Fig. 9d). All these features point to an extensive involvement of fractional crystallization processes in their petrogenesis.

As expected from an AFC-style petrogenetic model, the $\mathrm{Sr}-\mathrm{Nd}$ isotopic data for the different intrusive units tend to define a curved trend from crustal compositions towards positive ?Nd initial and low ?Sr initial values, typical of a depleted mantle component $(? \mathrm{Sri}=65.2$ to $1.4 ;$ ? $\mathrm{Ndi}=-4.0$ to +0.6) (Fig. 10). Fractional crystallization and hybridization between coeval mantle- and crust-derived magmas is therefore proposed as a major mechanism for the production of abundant volumes of granite magmas during the last stages of the Variscan orogeny in Iberia.

\section{Conclusions}

The clear episodicity documented by precise ID-TIMS$\mathrm{U}-\mathrm{Pb}$ data suggests that granite magmatism in the Iberian Massif did not simply reflect the continuous thermal evolution of a thickened continental crust. Instead, it appears to indicate that the production and emplacement of granite magmas was governed by discrete tectonic events affecting the whole crust-upper mantle system.

Combined isotopic and geochemical evidence supports a purely crustal derivation for the syn- $\mathrm{D}_{3}$, S-type, two-mica granites, through moderate degrees of partial melting of Proterozoic-Cambrian metasediments at mid crustal levels. A deeper origin involving anatexis of lower crustal metaigneous protoliths and possible hybridization with mantlederived magmas is proposed for the syn- $\mathrm{D}_{3}$ granodiorites and monzogranites. The late-post- $\mathrm{D}_{3}$ granodiorite-monzogranite and biotite-muscovite suites seem to correspond to hybrid magmas produced by mixing of anatectic crustal melts with a juvenile asthenospheric mantle component, followed by further contamination and extensive fractional crystallization (AFC processes).

\section{Acknowledgements}

Rui Dias is kindly acknowledged for having encouraged this publication, Peter Watkins for technical assistance with the ICP-AES analysis at Imperial College, Oscar Carvalho for field assistance and José Francisco Santos for fruitful discussions. We are also very grateful to Colombo
Tassinari, Liliane Petronilho and Kei Sato for technical help during sample preparation and $\mathrm{Rb}-\mathrm{Sr}$ and $\mathrm{Sm}-\mathrm{Nd}$ mass spectrometry at the University of São Paulo (Brasil). This investigation was carried out in the scope of two research projects (PRAXIS 2/2.1/CTA/94 and POCTI/CTA/ 35630/99), financially supported by the Portuguese Foundation of Science and Technology (FCT).

\section{References}

Ábalos, B., Carreras, J., Druguet, E., Escuder Viruete, J., Gómez Pugnaire, M.T., Lorenzo Álvarez, S., Quesada, C., Rodríguez Fernández, L.R. and Gil Ibarguchi, J.I. (2002). Variscan and Pre-Variscan Tectonics. In: The Geology of Spain. Gibbons, W. and Moreno M. T. (Eds.). Geological Society, London, 155-183.

Allègre, C.J. and Minster, J.F. (1978). Quantitative models of trace element behaviour in magmatic processes. Earth and Planetary Science Letters, 38, 1-25.

Atherton, M.P. (1984). The coastal Batholith of Peru. In: Andean magmatism: Chemical and isotopic constraints, Harmon, R.S. and Barreiro, B.A. (Eds.) Shiva, Nantwich, UK, 168-179.

Atherton, M.P. (1993). Granite magmatism. Journal of Geological Society of London, 150, 1009-1023.

Azevedo, M. R. (1996). Hercynian granitoids from the Fornos de Algodres Area (Northern Central Portugal). Unpublished PhD. Thesis, Imperial College, London, 440 pp.

Azevedo, M.R. and Nolan J. (1998). Hercynian late-post-tectonic granitic rocks from the Fornos de Algodres area (Northern Central Portugal). Lithos, 44, 1-20.

Beetsma, J.J. (1995). The late Proterozoic/Paleozoic and Hercynian crustal evolution of the Iberian Massif, N Portugal. Unpublished Ph.D. Thesis, Vrije University, Netherlands, 223 pp.

Burg, J-P., Van Den Driessche, J. and Brun, J-P. (1994). Syn- to post-thickening extension in the Variscan Belt of Western Europe: modes and structural consequences. Geologie de la France, 3: 33-51.

Capdevila R., Corretgé, L.G. and Floor, P. (1973). Les granitoides varisques de la Meseta Ibérique. Bulletin Societe Géologique de la France, 15, 209-228.

Capdevila, R., and Mougenot, D. (1988). Pre-Mesozoic basement of the western Iberian continental margin and its place in the Variscan Belt. In Boillot, G., Winterer, E.L., et al., Proc. ODP, Sci. Results, 103: College Station, TX (Ocean Drilling Program), 3-12.

Carrington da Costa, J. (1950). Notícia sobre uma carta geológica do Buçaco de Nery Delgado. Comunicações dos Serviços Geológicos de Portugal, 28 pp. 
Castro, A., Moreno-Ventas, I. and De La Rosa, J.D. (1994). Rocas plutónicas híbridas y mecanismos de hibridización en el Macizo lbérico Hercínico. Boletín Geológico y Minero de España, 105-3, 285-315.

Dallmeyer, R.D. and Gil Ibarguchi, J.I. (1990). Age of amphibolitic metamorphism in the ophiolitic unit of the Morais allochthon (Portugal): implications for early Hercynian orogenesis in the Iberian Massif: Journal of the Geological Society, London, 147, 873-878.

Dallmeyer, R.D., Martínez Catalán, J.R., Arenas, R., Gil Ibarguchi, J.I., Gutiérrez Alonso, G., Farias, P., Bastida, F., and Aller, J. (1997). Diachronous Variscan tectonothermal activity in the NW Iberian Massif: Evidence from 40Ar/39Ar dating of reginal fabrics. Tectonophysics, 277: 307-337.

Dias, R. (1994). Regimes de Deformação no Autóctone da ZCl: Importância para a compreensão da Génese do Arco lberoArmoricano. Ph.D. Unpublished PhD. Thesis, University of Lisbon (Portugal).

Dias, G. and Leterrier, J. (1994). The genesis of mafic-felsic plutonic associations: $\mathrm{A} \mathrm{Sr}$ and $\mathrm{Nd}$ isotopic study of the Hercynian Braga granitoid massif (Northern Portugal). Lithos, $32,207-223$

Dias, G., Simões, P.P., Ferreira, N. and Leterrier, J. (2002). Mantle and Crustal Sources in the Génesis of Late-Hercynian Granitoids (NW Portugal): Geochemical and Sr-Nd Isotopic Constraints. Gondwana Research, 5, 287-305.

Díez Balda, M.A., Vegas, R. and Gonzalez Lodeiro, F. (1990). Central Iberian Zone: Structure. In: Pre-Mesozoic Geology of the Iberian Peninsula, Dallmeyer, R.D and Martinez Garcia, E. (Eds.). Springer Verlag, Berlin, pp. 172-188.

Escuder Viruete, J., Arenas, R. and Martínez Catalán, J.R. (1994). Tectonothermal evolution associated with Variscan crustal extension in the Tormes Gneiss Dome (NW Salamanca, Iberian Massif, Spain). Tectonophysics, 238, 117-138.

Escuder Viruete, J., Indares, A. and Arenas, R. (2000). P-T path derived from garnet zoning in an extensional setting: an exemple from the Tormes Gneissic Dome (Iberian Massif, Spain). Journal of Petrology, 41, 1488-1518.

Evensen, N.H., Hamilton, P.J. and O'Nions, R.K. (1978). Rare earth abundances in chondrite meteorites. Geochimica et Cosmochimica Acta, 42, 1199-1212.

Farias, P., Gallastegui, G., González-Lodeiro, F., Marquínez, J., Martín Parra, L.M., Martínez Catalán, J.R., Pablo Maciá, J.G. de, and Rodríguez Fernández, L.R. (1987). Aportaciones al conocimiento de la litoestratigrafía y estructura de Galicia Central. Memórias da Faculdade de Ciências, Universidade do Porto, 1: 411-431.

Ferreira Pinto, A.F. (1983). Rochas granitóides Hercínicas posttectónicas da área de Sátão-Penalva do Castelo. Características petrológicas e geoquímicas. Memórias e Notícias, Univ. Coimbra, 96, 39-74.
Ferreira, N., Iglesias, M., Noronha, F., Pereira, E., Ribeiro, A. and Ribeiro, M.L. (1987). Granitóides da Zona Centro-lbérica e seu enquadramento geodinâmico. In: Geologia de los granitoides e rocas asociadas del Macizo Hespérico, Bea, F., Carnicero, A., Gonzalo, J.C., López Plaza, M. and Rodriguez Alonso, M.D. (Eds.) Editorial Rueda, Madrid, 37-53.

Gebauer, D., Martínez García, E. and Hepburn, J. C. (1993). Geodynamic significance, age and origin of the Ollo de Sapo augengneiss (NW Iberian massif, Spain) Annual Meeting GSA, Boston, Abst. with Prog. A-342.

Holtz, F. and Johannes, W. (1991). Genesis of peraluminous granites I. Experimental investigation of melt composition at 3 and $5 \mathrm{kbar}$ and various $\mathrm{H} 2 \mathrm{O}$ activities. Journal of Petrology, 32, 935-958.

Iglesias, M. and Ribeiro, A., (1981). La zone de cisaillement ductile de Juzbado (Salamanca)-Penalva do Castelo (Viseu): Un linéament ancien reactivé pendant l'orogenese Hercynienne? Comunicações dos Serviços Geológicos de Portugal, 67, 1: 89-93.

Julivert, M., Fontbote, J.M., Ribeiro, A. and Conde, L., (1974). Mapa Tectónico de la Península Ibérica y Baleares (Memoria). Instituto Geológico y Minero de España, Madrid. $113 \mathrm{pp}$.

Kwan, T.S., Krahenbul, R. and Jager, E. (1992). Rb-Sr, K-Ar and fission track ages for granites from Penang Island, West Malaysia: an interpretation model for $\mathrm{Rb}-\mathrm{Sr}$ whole-rock and for actual experimental mica data. Contributions to Mineralogy and Petrology, 111, 527-542.

La Roche, H., Leterrier, J., Grandclaude, P. and Marchal, M. (1980). A classification of volcanic and plutonic rocks using $\mathrm{R} 1-\mathrm{R} 2$ diagram and major element analysis. Its relationships with current nomenclature. Chemical Geology, 29, 183-210.

Macedo, C.A.R. (1988). Granitóides, Complexo Xisto Grauváquico e Ordovícico na região entre Trancoso e Pinhel - Geologia, Petrologia, Geocronologia. Unpublished Ph.D. Thesis, University of Coimbra, Portugal, 432 pp.

Matte, Ph. (1986). Tectonics and plate tectonics model for the Variscan belt of Europe: Tectonophysics, 126, 329-374.

Matte, Ph. and Burg, J.P. (1981). Structures thrusts and nappes in the Variscan Arc of western Europe: plate tectonic implications. In: Thrust \& Nappe Tectonics, K.R. Mc. Clay \& N.J. Price (edits.), Blackwell Sci. Publ., 353-358.

Mota Leite, S., Santos, J.F. and Azevedo, M.R. (2005). Variscan plutonism in the Castro Daire area (Northern Central Portugal) - constraints from U-Pb geochronology. The 6th International Symposium on Applied Isotope Geochemistry, Prague, Czech Republic. Abst. with Prog.

Neves, L.J.P.F. (1991). Tranferências de matéria e energia na interface granitóides biotíticos porfiróides-granitóides muscovítico biotíticos na região de Torredeita (Viseu, Portugal Central). Unpublished Ph.D. Thesis, University of Coimbra, Portugal, 240 pp. 
Noronha, F., Ramos, J.M.F., Rebelo, J.A., Ribeiro, A. and Ribeiro, M.L. (1981). Essai de corrélation des phases de déformation hercyniennes dans le nord-ouest Péninsulaire. Leidse Geol. Mededel, 52, 87-91

Oen, I.S. (1958). The geology petrology and ore deposits of the Viseu region, northern Portugal. Comunicações dos Serviços Geológicos de Portugal, 41, 199 pp.

Oen, I.S. (1970). Granite intrusion, folding and metamorphism in Central Northern Portugal. Boletin Geológico y Minero de España, 81, 271-298.

Ortega, L.A. and Gil Ibarguchi, J.I. (1989). The genesis of the late Hercynian granitoids from Galicia (Northwestern Spain): Inferences from REE studies. Journal of Geology, 98, 189-211.

Page, R.W. and Bell, T.H. (1986). Isotopic and structural responses to successive deformation and metamorphism. Journal of Geology, 94, 365-379.

Patiño Douce, A.E. and Beard, J.S. (1995). Dehydration-melting of biotite gneiss and quartz amphibolite from 3 to $15 \mathrm{kbar}$. Journal of Petrology, 36, 707-738.

Patiño Douce,A.E. and Johnston, A.D. (1991). Phase equilibria and melt productivity in the politic system: implications for the origin of peraluminous granitoids and aluminous granulites. Contributions to Mineralogy and Petrology, 107, 202-218.

Pereira, A. (1991). Tranferências de calor e ascensão crustal no segmento Tondela-Oliveira do Hospital (Portugal Central) após a implantação dos granitos hercínicos sin- a tardiorogénicos. Unpublished Ph.D. Thesis, University of Coimbra, Portugal.

Peucat, J.J., Bernard-Griffiths, J., Gil Ibarguchi, J.I., Dallmeyer, R.D., Menot, R.P., Cornichet, J., and Iglesias Ponce de León, M., (1990). Geochemical and geochronological cross section of the deep Variscan crust: The Cabo Ortegal high-pressure nappe (northwestern Spain): Tectonophysics, 177, p. 263-292.

Pinto, M.S., Casquet, C., Ibarrola, E., Corretgé, L.G. and Portuga Ferreira, M. (1987). Síntese geocronológica dos granitóides do Maciço Hespérico. In: Geologia de los granitoides e rocas asociadas del Macizo Hespérico, Bea, F., Carnicero, A., Gonzalo, J.C., López Plaza, M. and Rodriguez Alonso, M.D. (Eds.) Editorial Rueda, Madrid, 69-86.

Quesada, C. (1990). Precambrian terranes in the Iberian Variscan Fold Belt. In: Avalonian and Cadomian Geology of North Atlantic, Strachan, R.A. and Taylor, G.K. (Eds.), Blackie and Son, 109-133.

Quesada, C. (1991). Geological constraint on the Paleozoic tectonic evolution of tectonostratigraphic terranes in Iberian Massif. Tectonophysics, 185, 225-245.

Reavy, R.J. (1989). Structural controls on metamorphism and syn-tectonic magmatism: The Portuguese Hercynian collision belt. Journal of the Geological Society, London, 146, 649-657.
Ribeiro, A. (1981). A geotraverse through the Variscan Fold Belt in Portugal. Geologie en Mijnbouw, 60, 41-44.

Ribeiro, A., Conde, L. and Monteiro, J. (1972). Carta Tectónica de Portugal, E. 1: 1.000.000. Serviços Geológicos de Portugal.

Ribeiro, A., Pereira, E. and Severo, L. (1980). Análise da deformação na zona de cisalhamento Porto-Tomar na transversal de Oliveira de Azeméis. Comunicações dos Serviços Geológicos de Portugal, 66, 33-48

Ribeiro, A., Quesada, C. and Dallmeyer, R.D (1990). Geodynamic evolution of the Iberian Massif. In: Pre-Mesozoic Geology of the Iberian Peninsula, Dallmeyer, R.D and Martinez Garcia, E. (Eds.). Springer Verlag, Berlin, 399-409.

Schaltegger, U. (1997). Magma pulses in the Central Variscan Belt: episodic melt generation and emplacement during lithospheric thinning. Terra Nova 9, 242-245.

Schermerhorn, L.J.G. (1956a). Igneous, metamorphic and ore geology of the Castro Daire - São Pedro do Sul - Sátão region (northern Portugal). Comunicações dos Serviços Geológicos de Portugal, 37, $617 \mathrm{pp}$.

Simões, P.P. (2000). Instalação, geocronologia e petrogénese de granitóides biotíticos sintectónicos associados ao cisalhamento Vigo-Régua. Unpublished Ph.D. Thesis, University of Minho, Braga, Portugal, 351 pp.

Skjerlie, K.P. and Johnston, A.D. (1996). Vapour-absent melting from 10 to 20 kbar of crustal rocks that contain multiple hydrous phases: implications for anatexis in the deep to very deep continental crust and active continental margins. Journal of Petrology, 37, 661-691.

Sun, S. and McDonough, W.F (1989). Chemical and isotopic sistematics of oceanic basalts: implications for mantle compositions. In: Magmatism in the Ocean Basins, Sauders, A.D. and Norry, M.J. (Eds.). Special Publications of the Geological Society of London, 42, 313-345.

Tassinari, C.C.G., Medina, J. and Pinto, M.S., 1995. Rb-Sr and $\mathrm{Sm}-\mathrm{Nd}$ geochronology and isotope geochemistry of Central Iberian metasedimentary rocks (Portugal). Geologie en Mijnbouw, 75, 69-79

Schulmann K., Schaltegger U., Jezek J., Thompson A.B. and Edel J.B. (2002). Rapid burial and exhumation during orogeny: Thickening and synconvergent exhumation of thermally weakened and thinned crust (Variscan orogen in Western Europe). American Journal of Science 302, 856-879.

Shelley, D. and Bossière, G. (2000). Discussion on "A new model for the Hercynian Orogen of Gondwana France and Iberia". Journal of Structural Geology, 22, 757-776.

Silva, J.B., Oliveira, J.T. and Ribeiro, A. (1990). The South Portuguese Zone. Structural Outline. In: Pre-Mesozoic Geology of the Iberian Peninsula, Dallmeyer, R.D and Martinez Garcia, E. (Eds.). Springer Verlag, Berlin, 334-362. 
Silva, M.M.V.(1995). Mineralogia, petrologia e geoquímica de encraves de rochas graníticas de algumas regiões portuguesas. Unpublished Ph.D. Thesis, University of Coimbra, Portugal, 288 pp.

Sylvester, P.J. (1998). Post-collisional strongly peraluminous granites. Lithos, 45, 29-44.

Taylor, S.R. and McLennan, S.M. (1985). The continental crust: its composition and evolution. Blackwell, Oxford, 312 pp.

Teixeira, C. (1954). Os conglomerados do Complexo XistoGrauváquico ante-silúrico. Comunicações da Sociedade Geológica, Porto, 35: 33-49

Valle Aguado, B., Azevedo, M.R., Schaltegger, U., Martínez Catalán, J.R. \& Nolan, J. (2005). U-Pb zircon and monazite of Variscan magmatism related to syn-convergence extension in central northern Portugal. Lithos (in press).

Valle Aguado, B., Martínez Catalán, J.R. and Azevedo, M.R. (2000). Structure of the western termination of the Juzbado Penalva do Castelo Shear Zone (Western Iberian Massif). In: Variscan-Appalachian dynamics: the building of the Upper Paleozoic basement. Basament Tectonics 15, A Coruña, Spain, Program and Abstracts, 287-291.

Valverde Vaquero, P. (1997). An integrated field, geochemical and $\mathrm{U}-\mathrm{Pb}$ geochronological study of the SW Hermitage Flexure (Newfoundland Appalachians, Canada) and The Sierra de Guadarrama (Iberian Massif, Central Spain): a contribution to the understanding of the geological evolution of circum-Atlantic peri-Gondwana. Unpublished Ph.D. Thesis, Memorial University of Newfoundland, St. John's.

Villaseca, C., Barbero, L. and Rogers, G. (1998). Crustal origin of hercynian peraluminous granitic batholiths of central Spain: petrological, geochemical and isotopic $(\mathrm{Sr}, \mathrm{Nd})$ constraints. Lithos 43, 55- 79.

Villaseca, C., Downes, H., Pin, C. and Barbero, L. (1999). Nature and Composition of the Lower Continental Crust in Central Spain and the Granulite-Granite Linkage: Inferences from Granulitic Xenoliths. Journal of Petrology, 40, 1463-1496.

Watkins, P.J. and Nolan, J. (1990). Determination of rare-earth elements, scandium yttrium and hafnium in 32 geochemical reference materials using inductively coupled plasma-atomic emission spectrometry. Geostandards Newsletter, 14 (1), 11-20.

Watkins, P.J. and Nolan, J. (1992). Determination of rare-earth elements, yttrium, scandium and hafnium using cationexchange separation and inductively coupled plasma-atomic emission spectrometry. Chemical Geology, 95, 131-139.

\section{A. Tables}

Table A.1. Major, trace and REE element compositions for selected samples of the granitoids from the Beiras batholith




